\title{
Sulfate-rich crustal fluids and REE tranpsort
}

ZHONG, R.C. ${ }^{1 *}$, CUI, H. ${ }^{1}$, XIE, Y.L. ${ }^{1}$, BRUGGER, J. ${ }^{2,3}$, YUAN, X.Y. ${ }^{4}$, CHEN, H. ${ }^{1}$, LIU W.H. ${ }^{5}$, YU, C. ${ }^{1123}$

${ }^{1}$ Civil and Resource Engineering School, University of Science and Technology Beijing, Beijing 100083, China (*correspondence: zhongrichen@126.com)

${ }^{2}$ School of Earth, Atmosphere and the Environment, Monash University, Clayton, Victoria 3800, Australia

${ }^{3}$ South Australian Museum, North Terrace, Adelaide, South Australia 5000, Australia

${ }^{4}$ MLR Key Laboratory of Metallogeny and Mineral Assessment, Institute of Mineral Resources, Chinese Academy of Geological Sciences, Beijing 100037, China ${ }^{5}$ CSIRO Minerals Recourses, Clayton, Victoria, 3168, Australia

The presence of sulfate-rich fluids in natural magmatic hydrothermal systems and some carbonatite-related rare earth element (REE) deposits is paradoxical, because sulfate salts are known for their retrograde solubility, implying that they should be insoluble in hightemperature geofluids.

In our recent hydrothermal diamond anvil cell (HDAC) experiments in the $\mathrm{Na}_{2} \mathrm{SO}_{4}-\mathrm{SiO}_{2}-\mathrm{H}_{2} \mathrm{O}$ and $\mathrm{Na}_{2} \mathrm{SO}_{4}$ $\mathrm{Nd}_{2}\left(\mathrm{SO}_{4}\right)_{3}-\mathrm{SiO}_{2}-\mathrm{H}_{2} \mathrm{O}$ systems, we simulated the hightemperature behaviors of sulfate in the presence of excess quartz [1]. Sulfate-oversaturated systems are prepared at room temperature, by loading sulfate crystals, sulfatedsatureated aqueous solution, and a quartz piece as starting materials. The experiment was conducted from room temperature to $\sim 550{ }^{\circ} \mathrm{C}$.

In the $\mathrm{Na}_{2} \mathrm{SO}_{4}-\mathrm{SiO}_{2}-\mathrm{H}_{2} \mathrm{O}$ system, the experiemnts show that the presence of quartz can significantly change the dissolution behavior of $\mathrm{Na}_{2} \mathrm{SO}_{4}$, leading to the formation of extremely sulfate-rich fluids (at least $42.8 \mathrm{wt} \% \mathrm{Na}_{2} \mathrm{SO}_{4}$ ) at temperatures $>\sim 330{ }^{\circ} \mathrm{C}$. The elevated $\mathrm{Na}_{2} \mathrm{SO}_{4}$ solubility results from prograde dissolution of immiscible sulfate melt, the water-saturated solidus of which decreases from $\geqslant$ $\sim 450{ }^{\circ} \mathrm{C}$ in the binary $\mathrm{Na}_{2} \mathrm{SO}_{4}-\mathrm{H}_{2} \mathrm{O}$ system to $\sim 270{ }^{\circ} \mathrm{C}$ in the presence of silica. Similar results were observed in the $\mathrm{Na}_{2} \mathrm{SO}_{4}-\mathrm{Nd}_{2}\left(\mathrm{SO}_{4}\right)_{3}-\mathrm{SiO}_{2}-\mathrm{H}_{2} \mathrm{O}$ system, and prograde dissolution of the Na-Nd-sulfate melting leaded to the formation an extremly Nd- and sulfate-rich fluid at $\sim 420^{\circ} \mathrm{C}$.

These findings imply that sulfate-rich fluids should be common in quartz-saturated crustal environments and can be effective medium for REE mobilization.

[1] Cui, H. et al. (2020), Geology 48, 145-148. 